\title{
Deformation induced martensite in AISI 316 stainless steel $I^{(\bullet)}$
}

\author{
N. Solomon* and I. Solomon ${ }^{* *}$
}

\begin{abstract}
The forming process leads to a considerable differentiation of the strain field within the billet, and finally causes the non-uniform distribution of the total strain, microstrusture and properties of the material over the product cross-section. This paper focus on the influence of stress states on the deformation-induced a' martensitic transformation in AISI Type 316 austenitic stainless steel. The formation of deformation-induced martensite is related to the austenite $(\gamma)$ instability at temperatures close or below room temperature. The structural transformation susceptibility is correlated to the stacking fault energy (SFE), which is a function not only of the chemical composition, but also of the testing temperature. Austenitic stainless steels possess high plasticity and can be easily cold formed. However, during cold processing the hardening phenomena always occurs. Nevertheless, the deformation-induced martensite transformation may enhance the rate of work-hardening and it may or may not be in favour of further material processing. Due to their high corrosion resistance and versatile mechanical properties the austenitic stainless steels are used in pressing of heat exchanger plates. However, this corrosion resistance is influenced by the amount of martensite formed during processing. In order to establish the links between total plastic strain, and martensitic transformation, the experimental tests were followed by numerical simulation.
\end{abstract}

Keywords

Plastic deformation at low temperature; Austenitic stainless steel; Strain-induced martensitic transformation; Numerical simulation.

\section{Martensita inducida por deformación en un acero inoxidable AISI 316}

\begin{abstract}
Resumen El proceso de conformación da a lugar a una considerable diferenciación del campo de tensiones dentro de una barra de extrusión y, finalmente, causa una distribución no uniforme de la tensión total, la microestructura y propiedades del material sobre el corte transversal. En este trabajo se estudia la influencia de los estados de tensión sobre la transformación martensítica inducida por deformación en un acero inoxidable austenítico tipo AISI 316. La formación de martensita inducida por deformación esta relacionada con la estabilidad de la austenita $(\gamma)$ a temperaturas cercanas o inferiores a la temperatura ambiente. La susceptibilidad a esta transformación estructural esta correlacionada con el valor de la energía de falta de apilamiento, la cual es función de la composición del acero y de la temperatura de ensayo. Los aceros austeníticos poseen una elevada plasticidad y pueden ser fácilmente conformados en frío. Sin embargo, durante el proceso de deformación en frío, se puede producir un incremento adicional del endurecimiento por deformación asociado a la transformación martensítica inducida durante la deformación, el cual puede mejorar las propiedades posteriores de procesado. Debido a su alta resistencia a la corrosión y buenas propiedades mecánicas, los aceros inoxidables austeníticos se utilizan para la fabricación de placas intercambiadoras de calor. Sin embargo, la cantidad de martensita formada durante el procesado tendrá una influencia sobre la resistencia a la corrosión. Se realizaron ensayos de simulación numérica para correlacionar la deformación plástica total con la transformación martensítica.
\end{abstract}

Palabras clave Deformación plástica en frío; Acero inoxidable austenítico; Transformación martensítica inducida por deformación; Simulación numérica.

\section{INTRODUCTION}

Directionality of strain during plastic deformation process considerably affects the product quality its structure and properties, the process efficiency and the deformation force amplitude. The anisotropic values of basic properties (strain and strain hardening) in the deformed material present importance to ensure the final mechanical characteristics of the parts for an appropriate behavior in working condition ${ }^{[1-3]}$.

\footnotetext{
(•) Trabajo recibido el día 13 de abril de 2009 y aceptado en su forma final el día 24 de noviembre de 2009.

* "Stefan cel Mare" Suceava University, Str. Universitatii nr.13, 720228 Suceava, Romania.

** (Former Associate Professor) "Dunarea de Jos”, Galati University, Str. Domneasca nr.47, 6200 Galati, Romania.
} 
Austenitic stainless steels are extensively used in different industrial applications and therefore it is very important to control their microstructure evolution, physical and mechanical properties. It is known that in the case of such materials plastic deformation can induce transformation of austenite into martensite. According to Perdahcioğlu et al. the initiation of transformation will always be from a virgin $100 \%$ austenite material ${ }^{[4]}$.

In austenite stainless steels the deformation process can induce the formation of two types of martensite:

\section{Austenite $\gamma(\mathrm{FCC}) \rightarrow$ martensite $\varepsilon(\mathrm{HCP}) \rightarrow$ martensite $\alpha^{\prime}(\mathrm{BCC})$}

The transformation sequence above mentioned was proposed by some authors ${ }^{[5}$ and 6$]$. However, the direct transformation $\gamma \rightarrow \alpha^{\prime}$ through dislocation reactions was found to be possible $\mathrm{e}^{[7 \text { and } 8]}$. But it is also suspected that $\varepsilon$-martensite forms at lower temperatures $\left(-50^{\circ} \mathrm{C}\right)^{[4]}$. The amount of deformation induced martensite depends upon several factors such as: material chemistry, temperature, plastic strain, strain rate, stress state, deformation mode, grain size, grain orientation, etc. ${ }^{[5,9}$ and 10$]$. The increase of $\alpha$ ' martensite by martensitic transformation induced by plastic deformation causes a change in physical properties of austenitic stainless steels ${ }^{[11]}$.

Eichelman and Hull had developed an equation which gives an approximation of $\alpha$ 'martensite formation temperature - Ms:

$$
\begin{aligned}
& \text { Ms }\left({ }^{\circ} \mathrm{C}\right)=1302-42(\% \mathrm{Cr})-61(\% \mathrm{Ni})- \\
& 33(\% \mathrm{Mn})-28(\% \mathrm{Si})-1667(\%[\mathrm{C}+\mathrm{N}])
\end{aligned}
$$

The necessary energy for the martensite transformation can be supplied by the plastic deformation process. On the other hand, there is a temperature about which martensite can not form under deformation, $\mathrm{Md}$. Thus, $\mathrm{Md}$ is the temperature which limits deformation induced martensitic transformation. Angel et al. have studied the dependence of temperature with composition for different steels and formulated equation $2^{[5]}$.

$$
\begin{gathered}
\operatorname{Md}(30 / 50)\left({ }^{\circ} \mathrm{C}\right)=413-13.7(\% \mathrm{Cr})- \\
9.5(\% \mathrm{Ni})-8.1(\% \mathrm{Mn})-18.5(\% \mathrm{Mo})- \\
9.2(\% \mathrm{Si})-462(\%[\mathrm{C}+\mathrm{N}])
\end{gathered}
$$

$\mathrm{Md}$ is the temperature at which $50 \%$ of the $\alpha$-martensite is produced after $30 \%$ true deformation under tensile condition.
Even though stainless steels are known having a good resistance to general corrosion because they form

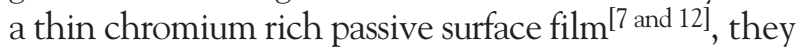
are susceptible to localized corrosion attack such as pitting, intergranular corrosion, and stress corrosion

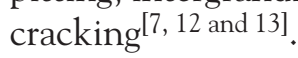

This paper is focused on the influence of stress states on deformation-induced $\alpha$ ' martensitic transformation in AISI type 316 austenitic stainless steel in the form of round bars and metallic sheets. It is also analyzed the influence of martensite formation on the corrosion resistance of austenitic stainless steel. Corrosion analysis showed that martensitic transformation which occurs due to plastic deformation process had a substantially influence on the corrosion resistance of heat exchanger plates made by AISI type 316 austenitic stainless steel. In order to study the influence of cold plastic deformation processes on martensitic transformation test samples of $\varnothing 10.8 \mathrm{~mm}$ diameter and $176 \mathrm{~mm}$ length from round bars and $90 \mathrm{~mm}$ width and $300 \mathrm{~mm}$ length from metallic sheets of $0.8 \mathrm{~mm}$ thickness, were manufactured. The round samples were deformed at room temperature through cold extrusion process. In the case of flat samples, instead of using for their deformation the deep drawing process which requires an expensive die, the Erichsen test (ISO-20483:2003), which is a cupping test to measure the ductility of a piece of sheet metal and to determine its suitability for deep drawing process, was used.

\section{EXPERIMENT AND ANALYSIS}

Samples of AISI 316 austenitic stainless steels in cold formed as initial state with the following chemical composition: $0.04 \%$ C, $0.51 \% \mathrm{Si}, 1.48$ \% Mn, $0.021 \%$ P, $0.002 \%$ S, $17.05 \%$ Cr, $10.53 \%$ $\mathrm{Ni}, 2.05 \% \mathrm{Mo}, 0.44 \% \mathrm{Cu}, 0.05 \% \mathrm{~V}$ and $0.03 \%$ Ti were used for investigation ${ }^{[7}$ and 12].

$\mathrm{Ms}$ and $\mathrm{Md}$ (30/50) temperatures were calculated with Equations 1 and 2 and their values are $-186.2^{\circ} \mathrm{C}$ and $6.3{ }^{\circ} \mathrm{C}$ respectively. A Ms temperature of $-186.2^{\circ} \mathrm{C}$ serves to indicate that cooling to absolute zero would not induce transformation. Md (30/50) which refers to the temperature that $50 \%$ of austenite is transformed to martensite with $30 \%$ of deformation, suggest that the formation of martensite at room temperature is very possible.

The microstructural analysis (Fig. 1) done on round samples in initial state, electrolitically etched with $50 \%$ distilled water solution plus $50 \% \mathrm{HNO}_{3}$, highlighted an austenitic structure with annealing twins and some non-metallic inclusions, which are 
DEFORMATION INDUCED MARTENSITE IN AISI 316 STAINLESS STEEL MARTENSITA INDUCIDA POR DEFORMACIÓN EN UN ACERO INOXIDABLE AISI 316

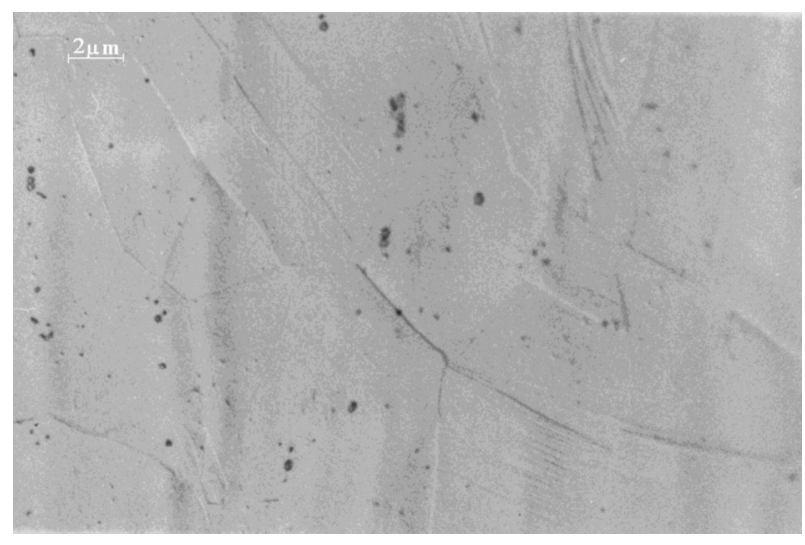

Figure 1. AISI 316stainless steel microstructure in the initial state, 100X.

Figura 1. Microestructura del acero inoxidable AISI 316 en el estado inicial, 100X.

identified as oxides, carbonitrides and globular silicate according to the standard. The average ASTM grain size of all samples was 7.4. The austenite stability decreases with increasing grain size. Thus, coarse-grained austenite will be more susceptible to martensitic transformation ${ }^{[9]}$.

Mechanical properties of AISI 316 austenitic stainless steel are shown in table $\mathrm{I}^{[2]}$ : Formation of strain induced martensite contributes to reach higher values for hardness and increases the ultimate tensile strength of this austenitic steel.

The martensitic transformation of AISI 316 austenitic stainless steel samples has been investigated
Table I. Mechanical properties of AISI 316 austenitic stainless steel used for this study (SS-EN 10 002-1)

Tabla I. Propiedades mecánicas del acero inoxidable autenítico AISI 316 usado para este estudio

\begin{tabular}{llll} 
Material & $\mathbf{R}_{\mathrm{p} 0.2}{ }^{*}$ & $\mathbf{R}_{\mathrm{m}}{ }^{*}$ & $\mathbf{A}_{5}$ \\
\hline AISI 316 & 272 & 620 & 52.3
\end{tabular}

${ }^{*} \mathrm{R}_{\mathrm{p} 0.2}, \mathrm{R}_{\mathrm{m}}$-are in $\mathrm{MPa}$.

by $\mathrm{X}$-ray diffraction $(\mathrm{XRD})$ with $\mathrm{Cu}-\mathrm{K} \cdot$ radiation using a RIGAKU diffractometer. Some results of the X-ray diffraction patterns performed on extruded samples (extrusion ratio, $\varepsilon=1.42$ ) are presented in figure 2 . The diffractogram shows only phases $\gamma$ and $\alpha$. There is no peak indicating the presence of $\varepsilon$ martensite. This means that $\varepsilon$ martensite is or can be only a step of martensite transformation. In this work probably the reaction $\gamma \varepsilon \rightarrow \alpha^{\prime}$ has been completed or the cold deformation generated only $\gamma \rightarrow \alpha$ ' reaction ${ }^{[5]}$.

The martensite transformation involves a suddenly reorientation of $\mathrm{C}$ and $\mathrm{Fe}$ atoms from the fcc solid solution of $\gamma$-Fe (austenite) to a body centered cubic (bcc) solid solution, which is martensite. The phase transformation is accompanied by volume

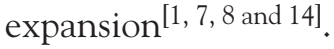

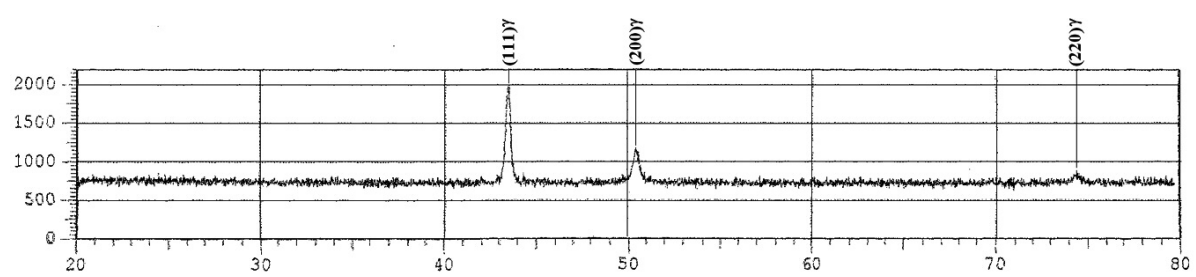

a)

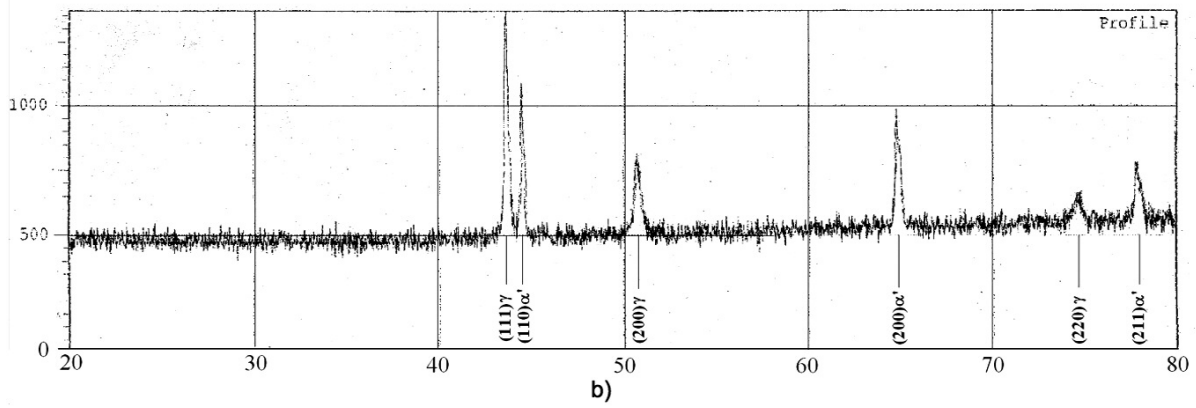

Figure 2. X-ray diffraction pattern: a) before deformation-initial state b) after deformation-extrusion.

Figura 2. Espectro de difracción de rayos X: a) antes de deformación; b) después de deformación. 


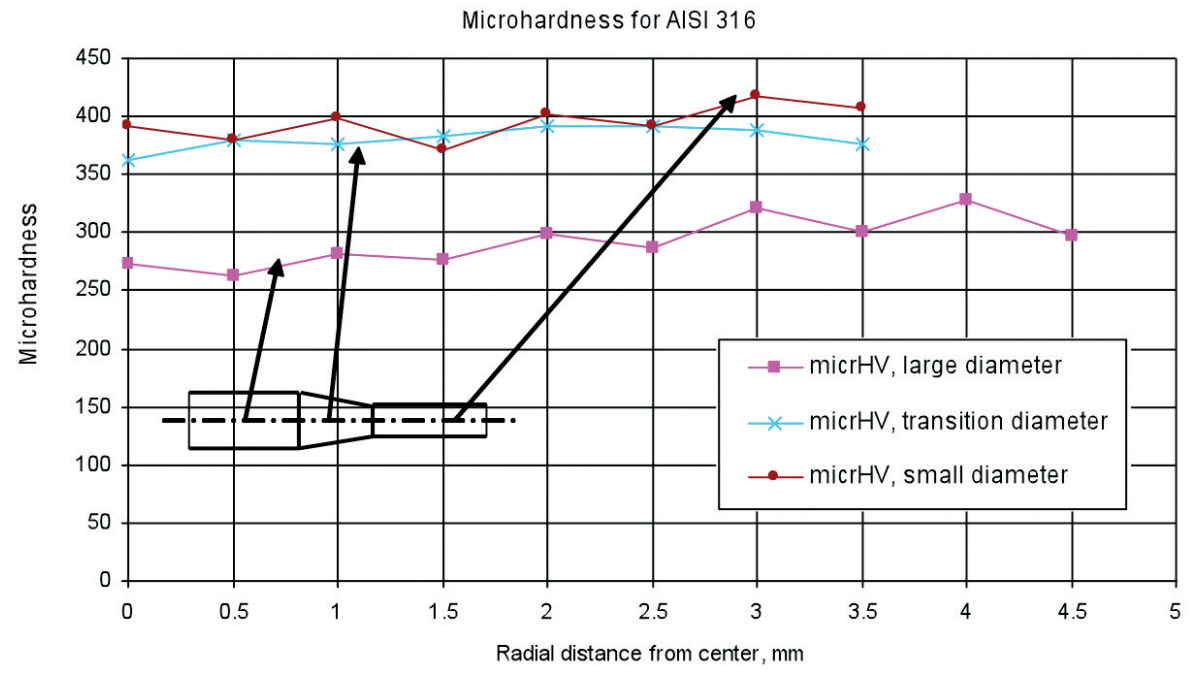

Figure 3. Microhardness of AISI 316 as a function of the radial distance from center.

Figura 3. Micro dureza de AISI316 en función de la distancia radial al centro.

The measurement of Vickers microhardness was done with $200 \mathrm{~g}$ load. Figure 3 shows the microhardness distribution before and after extrusion, as a function of the radial distance from center.

Similar to the thermal stress which occurs and determines martensite transformation during heat treatment, the stress due to plastic deformation process determines sliding of reciprocal displacement of the adjacent atoms with fraction of their interatomic distance.

\section{NUMERICAL SIMULATION ANALYSIS}

The deformation behavior of the stainless steels at low temperatures has been also analyzed using finite element (FE) code MARC/AutoForge. The finite element analysis (FEA) was aimed at obtaining knowledge about the material flow and the stress, strain and temperature distributions necessary to optimize the extrusion process. As an aim, a stable numerical simulation process should be achieved. In its initial state, the workpiece was at room temperature. However, during the process, the part was heated due to dissipation. For that reason, the FE simulation was carried out as an isothermal, axisymmetric problem applying quadrilateral elements. The material behaviour is governed by the incremental theory, the Von Misses yield criterion, the isotropic hardening rule ${ }^{[15}$ and 16$]$. Figure 4 presents the total equivalent plastic strain diagram of AISI 316 austenitic stainless steel extruded

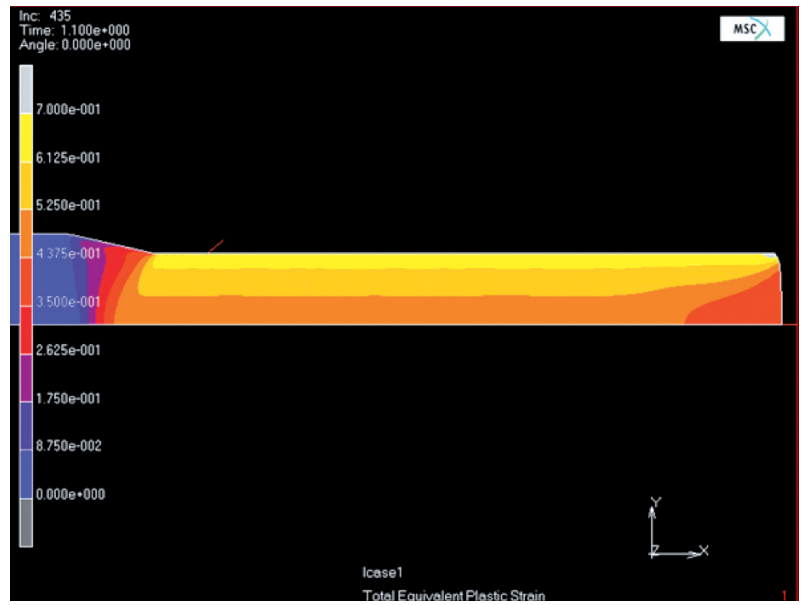

Figure 4. FEA total equivalent plastic strain diagram of 316 austenitic stainless steel cold extruded.

Figura 4. Diagrama de tensión plástica total FEA de acero inoxidable austenítico extruído en frío.

with a deformation ratio of $\varepsilon=1.42$, which is defined as $\varepsilon=\mathrm{D}^{2} / \mathrm{d}^{2}$ (D initial diameter, $\mathrm{d}$-extruded diameter).

The volume percentage of $\alpha$ ' martensite (M) (or austenite $(1-M)$ percentage) was found to be dependent on temperature and the level of plastic strain $^{[17]}$. Based on the above mentioned consideration and experimental extrusion test, the mathematical model to predict the volume of austenite phase can be formulated ${ }^{[18]}$ :

$$
\log (1-\mathrm{M})=\mathrm{K}^{*} \varepsilon_{\mathrm{T}}
$$


where, (1-M) represents the volume fraction of austenite phase; and $\mathrm{K}$ is a parameter which shows the tendency toward deformation induced martensitic transformation as a function of temperature. In the case of AISI 316 austenitic stainless steel extruded at room temperature, it can take the values showed on table II. $\varepsilon_{\mathrm{T}}$ represents the total plastic strain.

The total equivalent plastic strain diagram obtained by numerical simulation allows us easily to determine the amount of deformation during extrusion process and consequently the volume fraction of austenite phase. Taking into account the total equivalent plastic strain values (Fig. 4) and $\mathrm{K}$ parameter values from table II, equation (3) gives a value of $33.98 \%$ for the volume fraction of austenite phase in the outer layers of the extruded part. The $\alpha$ ' martensitic transformation occurs with an increase of tensile hydrostatic stress, or in other words, with an increase of mean normal stress which assists volume expansion.

\section{RESULTS AND DISCUSSION}

Austenitic steels possess high plasticity and can be cold-formed. However, depending on the value of the stacking fault energy, austenite is not a stable

Table II. K parameter values as a function of the temperature

Tabla II. Valores del parámetro K en función de la temperatura

\begin{tabular}{ccccc}
\hline Temperature, $\mathrm{T}\left[{ }^{\circ} \mathrm{C}\right]$ & $\mathbf{0}$ & $\mathbf{1 0}$ & $\mathbf{2 0}$ & $\mathbf{5 0}$ \\
\hline $\mathrm{K}$ & 3.00 & 2.50 & 2.00 & 0.80
\end{tabular}

phase during cold processing, and transform to martensite. Deformation induced martensite may enhance the work hardening and favor further material processing. The presence of $\alpha$ ' martensite in the microstructure of AISI 316 austenitic stainless steel deformed at room temperature was confirmed by the X-ray diffraction pattern of figure $2 \mathrm{~b}$ ). As figure 2 a) shows only the presence of $\gamma$ austenite, it was concluded that martensite phase were generated during the deformation process. Beside a decrease in intensity of $\gamma$ austenite peaks, Fig. 2b) shows also a broadening of these peaks, which was associated to an increase of microstrain in austenite. Thus, both deformation mechanisms, dislocation glide and formation of martensite, occur during plastic deformation. The results of the X-ray phase analysis have been gathered in figure 2 and table III.

On the other hand, $\alpha$ martensite volume fraction in the structure can be calculated from the X ray diffraction pattern using the following formula ${ }^{[19]}$ :

$$
\% \text { austenite }(1-\mathrm{M})=\left[\mathrm{I}_{\gamma} /\left(\mathrm{I}_{\gamma}+3.38 \mathrm{I}_{\alpha}\right)\right]^{*} 100 \%
$$

In equation (4), $\mathrm{I}_{\gamma}$ and $\mathrm{I}_{\alpha}$, are the integrated intensity ratios of $\gamma$ and $\alpha^{\prime}$ peaks, respectively. A value of $65 \%$ of $\alpha^{\prime}$ martensite is obtained.

Due to their superior corrosion resistance, good formability and toughness the austenitic stainless steels are used in plate heat exchanger applications. AISI 316 stainless steel is used for pressing of heat exchanger plates ${ }^{[2]}$. It has good corrosion behaviour, considering the fluid action (chlorine-treated water) in the heating circuit as well as in the secondary circuits. The working conditions of heat exchangers were the same as the testing conditions which are presented in table IV ${ }^{[12]}$ :

The influence of the deformation process on the corrosion resistance of AISI 316 stainless steel was also analyzed on the heat exchanger plates

Table III. Strongest $X$ ray diffraction peaks

Tabla III. Picos de difracción de rayos $X$ más intensos

\begin{tabular}{ccccccccc}
\hline no. & Peak no. & $\begin{array}{c}\text { 2Theta } \\
\text { (deg) }\end{array}$ & $\begin{array}{c}\text { d } \\
\text { (A) }\end{array}$ & I/II. & $\begin{array}{c}\text { FWHM } \\
\text { (deg) }\end{array}$ & $\begin{array}{c}\text { Intensity } \\
\text { (Counts) }\end{array}$ & $\begin{array}{c}\text { Integrated Int. } \\
\text { (Counts) }\end{array}$ & Phase \\
\hline 1 & 16 & 43.6192 & 2.07336 & 100 & 0.27450 & 561 & 8607 & $\gamma(111)$ \\
2 & 17 & 44.4793 & 2.03524 & 63 & 0.24920 & 353 & 4657 & $\alpha^{\prime}(110)$ \\
3 & 22 & 50.7043 & 1.79901 & 36 & 0.36860 & 203 & 3874 & $\gamma(200)$ \\
4 & 34 & 64.7847 & 1.43789 & 57 & 0.27160 & 322 & 4784 & $\alpha^{\prime}(200)$ \\
5 & 38 & 74.5843 & 1.43789 & 14 & 0.35140 & 77 & 1409 & $\gamma(220)$ \\
6 & 42 & 77.8239 & 1.22635 & 33 & 0.27660 & 183 & 2557 & $\alpha^{\prime}(211)$ \\
\hline
\end{tabular}


Table IV. Testing conditions

Tabla IV. Condiciones de ensayo (Condiciones de trabajo)

\begin{tabular}{lccc}
\hline \multirow{2}{*}{ Parameter } & \multicolumn{2}{c}{ Heating agent } & Measurement \\
& warm & cold & units \\
\cline { 2 - 4 } & water & water & - \\
\hline Fluid type & \multicolumn{2}{c}{$6.5-7.5$} & unit $\mathrm{pH}$ \\
- $\mathrm{pH}$ & \multicolumn{2}{c}{$22.18-83.75$} & $\mathrm{mg} / \mathrm{l}$ \\
-Chlorine-treated water & 10 & 10 & $\mathrm{bar}$ \\
Extreme pressure & 65 & 12 & ${ }^{\circ} \mathrm{C}$ \\
Input temperature & 40 & 52 & ${ }^{\circ} \mathrm{C}$ \\
Output temperature & $0.2-0.3$ & $0.2-0.3$ & $\mathrm{bar}$ \\
Safe working pressure dropping & $80 / 50$ & $12 / 62$ & ${ }^{\circ} \mathrm{C}$ \\
Extreme winter temperature & $80 / 52$ & \\
\hline
\end{tabular}

supplied by SC Apaterm SA Galati. The plate heat excenger consists of a pack of corrugated metal plates and is universally used for heating, cooling and heat recovery in chemical processing, food processing, etc.

The plates of heat exchanger were produced by the deep drawing process (Fig. 5) [2 and 12] $^{\text {The initial }}$ sheet thickness was $0.8 \mathrm{~mm}$ and the mechanical properties of AISI 316 austenitic stainless steel are presented in table $\mathrm{I}^{[2]}$.

In figure 5 it can be noticed that almost all surfaces of the plate are exposed to stretching or overstretching which favours martensite transformation. Harder than austenite, during the deep drawing process martensite can determine material failure. In the case of deformed plate three types of failures could be possible, failure at apex, failure at channel or failure at short end of channel[ ${ }^{[2}$ and 12]. The failure could be either necking or/and fracture such as in figure 6 .

Corrosion analysis showed that martensitic transformation which occurs due to plastic deformation had a substantially influence on the corrosion resistance of heat exchanger plates made by AISI 316 austenitic stainless steel [7,13 and 20].

The number of pits increases with deformation is associated to defects introduced by the deformation
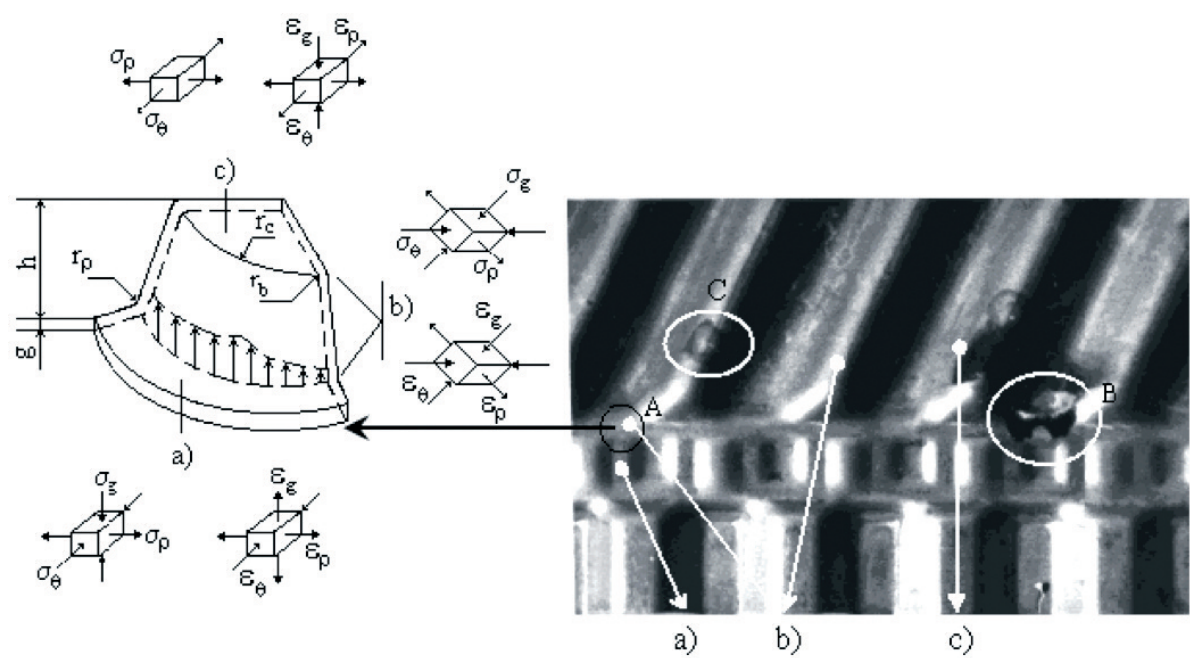

Figure 5. Heat exchanger deformed plate- short end of the channel. A) deformed zone; B) corroded zone; C) start up of pitting corrosion (pit)a, b, c: stress and strain state in deformed plate zones.

Figura 5. Placa intercambiadora de calor deformada parte final del canal A) zona deformada, B) zona corroída, C) inicio de corrosión a.b.c: estados de tensión y deformación en las zonas de plato deformado. 
DEFORMATION INDUCED MARTENSITE IN AISI 316 STAINLESS STEEL MARTENSITA INDUCIDA POR DEFORMACIÓN EN UN ACERO INOXIDABLE AISI 316

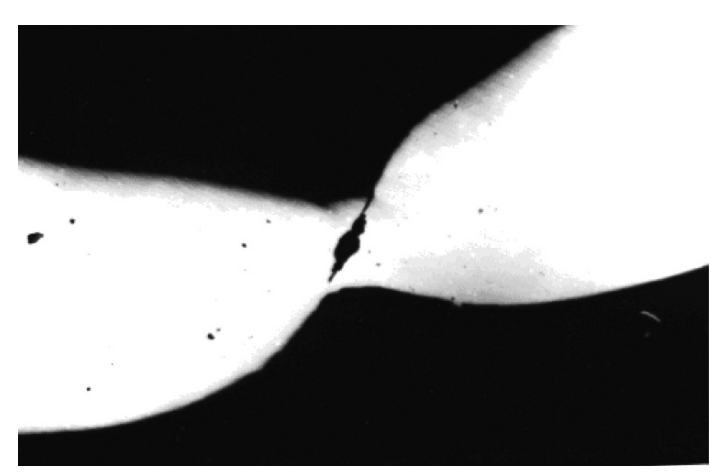

Figure 6. Necking and fracture in deformed zone.

Figura 6. Estricción y Fractura en la zona deformada.

process leading the arisen of preferential sites for pits

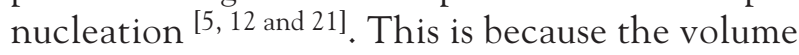
fraction of martensite is not constant though the plate due to different amount of plastic strain. This different amount of plastic strain produced harder zones due to the presence of a higher density of dislocations and a higher volume fraction of martensite, and consequently less resistant to corrosion.

The austenitic stainless steels are susceptible to some types of corrosion, namely pitting, crevice, stress corrosion cracking and sensitization (Fig. 7). Note the deep undercutting which is typical of chloride-induced attack on stainless steel. Pitting is induced in the presence of crevices or impurities such as sand, dirt, etc. Corrosion crevice may vary in appearance from almost uniform attack up to pitting at the metallic surface. Any aggressive solution (acid or neutral), including natural waters, but especially those containing chlorine anions are the ones resulting most frequently in this type of corrosion $^{[21]}$.

\section{CONCLUSIONS}

In AISI 316 austenitic stainless steel deformation induced $\alpha$ ' martensitic transformation forms by plastic deformation. However this transformation does not occur homogeneously in the whole material, since the volume fraction of martesite formed is a function of the amount of deformation. The local differences in fundamental characteristics (strain and strain hardening) are to be considered for an appropriate understanding of the behaviour of plates in use. In the case of deformed plate three types of failures could be possible, failure at apex, failure at channel or failure at short end of channel. The failure could be either necking or/and fracture either at the apex or along the channels of the herring - bone pattern. On the plate the volume fraction of martensite is not constant though the plate due to different amount of plastic strain. This different amount of plastic strain produced harder zones due to the presence of a higher density of dislocations and a higher volume fraction of martensite. These zones are consequently less resistant to corrosion.

Obtained results with the help of numerical simulation are compared to experimental ones.

\section{REFERENCES}

[1] M. Sanga, N. Yukawa and T. Ishikawa, Proc. ISAEM-97, Toyohashi, Japan, 1997, M. Umemoto and S. Kobayashi (Eds.), Toyohashi, Japan, 1997.

[2] P. Gabrielson, E. Schedin and G. Ekstrand, Proc. 6th ICTP, Vol. II, Nuremberg, Germany, 1999, M.Geiger (ed.), Springer, Germany, 1999, pp.1383-1388.

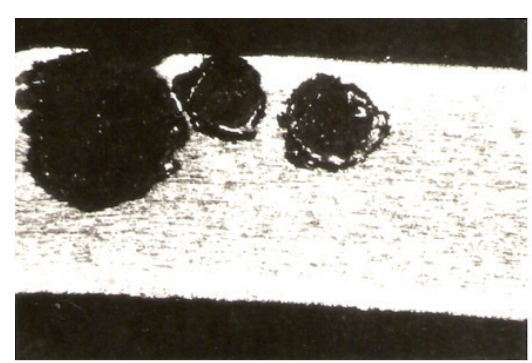

a)

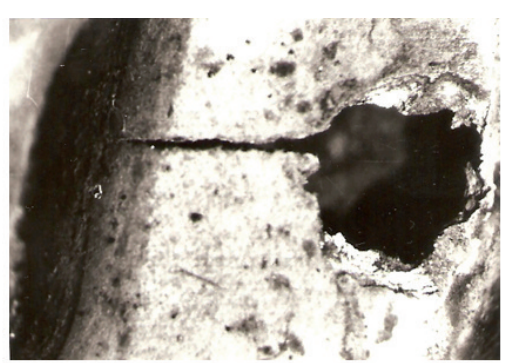

b)

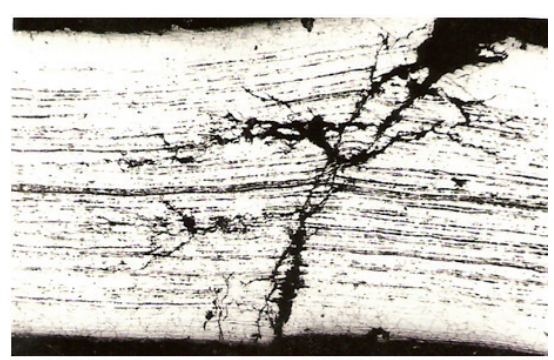

c)

Figure 7. Types of Corrosion: a) Pitting corrosion. b) Crevice corrosion. c) Stress corrosion.

Figura 7. Tipos de Corrosión: a) corrosión por picaduras. b) grietas de corrosión. c) corrosión bajo tensión. 
[3] N. Solomon and I. Solomon, Proc. 2nd Int. Seminar. Precision Forging, Osaka, Japan, 2000, pp. 175-181.

[4] E. S. Perdahcioğlu, H.J.M. Geijselaers and M. Groen, Scr. Mater. 58 (2008) 947-950.

[5] H.F. Gomes de Abreua, S. Santana de Carvalhoa, Pedro de Lima Netoa, R. Pires dos Santosa, V.N. Freirea, P. Maria de Oliveira Silvab and S.S.M. Tavaresc, Mater. Res. 10 (2007) 359-366.

[6] Z. Tourki, Z. Ktari, H. Sidhom and A. Gahbiche, 18ème CFM2007, Grenoble, France, 2007, L'édition électronique à l'INIST-CNRS, France, 2008, pp. CFM2007-0933.

[7] I. Solomon and N. Solomon, Studiul materialelor/Materials Science, Ed. OID, Bucharest, Romania, 1999, pp. 157-203.

[8] S. Grigull, Textures and Microstruct. 35 (2003) 153-162.

[9] H. Mirzadeh and A. Najafizadeh, Mater. Charact. 59 (2008)1650-1654.

[10] J. Talonen and H. Hänninen, Acta Mater. (2007) 6108-6118.

[11] W. Ozgowicz and A. Kurc, J Achiev. Mater. Manuf. Eng. (2009) 19-26.
[12] N. N., Contract 248/1999, Research on corrosion behaviour of heat exchanger plates from Apaterm SA, Galati, Romania, 1999.

[13] K. Chandra, V. Kain and P. Ganesh, J Mater. Eng. Perform. 17 (2008)115-122.

[14] J. Ch. Videau, G. Cailletaud and A. Pineau, J. Phys. III 4 (1994) 227-232.

[15] O.C. Zienkiewicz, The Finite Element Method, Third Edition, McGraw-Hill, London, UK, 1977, pp. 350-443.

[16] N. N., MARC/AutoForge/User manual.

[17] K. Mumtaz, S. Takahashi, J. Echigoya, Lf. Zhang, Y. Kamada and M. Sato, J Mater. Sci. 38 (2003) 3037-3050.

[18] N. Nishura, F. Fujita, R. Yagi, N. Suzuki, S. Murata, Proc. 6th ICTP, Vol. I, Nuremberg, Germany, 1999, M.Geiger (Ed.), Springer, Germany, 1999, pp.183-188.

[19] C. Gheorgies, Controlul structurii fine a metalelor $\mathrm{cu}$ radiatii $X /$ Metals fine structure control with X-ray diffraction, Ed Tehnica, Bucuresti, Romania, 1990, pp. 242-271.

[20] H. Leidkeiser, Corros. Sci. 22 (1982) 1089 1096.<

[21] J. C. Tverberg, MBAA TQ 38 (2001) 67-82. 